Actualité internationale de la littérature critique sur l'art

contemporain

43 | Automne 2014

CRITIQUE D'ART 43

\title{
Esther Ferrer
}

\section{Ramon Tio Bellido}

Translator. Helen Tomlinson

\section{(2) OpenEdition}

\section{Journals}

Electronic version

URL: http://journals.openedition.org/critiquedart/15355

DOI: 10.4000/critiquedart.15355

ISBN: 2265-9404

ISSN: 2265-9404

\section{Publisher}

Groupement d'intérêt scientifique (GIS) Archives de la critique d'art

\section{Printed version}

Date of publication: 15 November 2014

ISBN: $1246-8258$

ISSN: 1246-8258

\section{Electronic reference}

Ramon Tio Bellido, «Esther Ferrer », Critique d'art [Online], 43 | Automne 2014, Online since 15

November 2015, connection on 20 April 2019. URL : http://journals.openedition.org/

critiquedart/15355; DOI : 10.4000/critiquedart.15355

This text was automatically generated on 20 April 2019.

EN 


\section{Esther Ferrer}

\section{Ramon Tio Bellido}

Translation : Helen Tomlinson

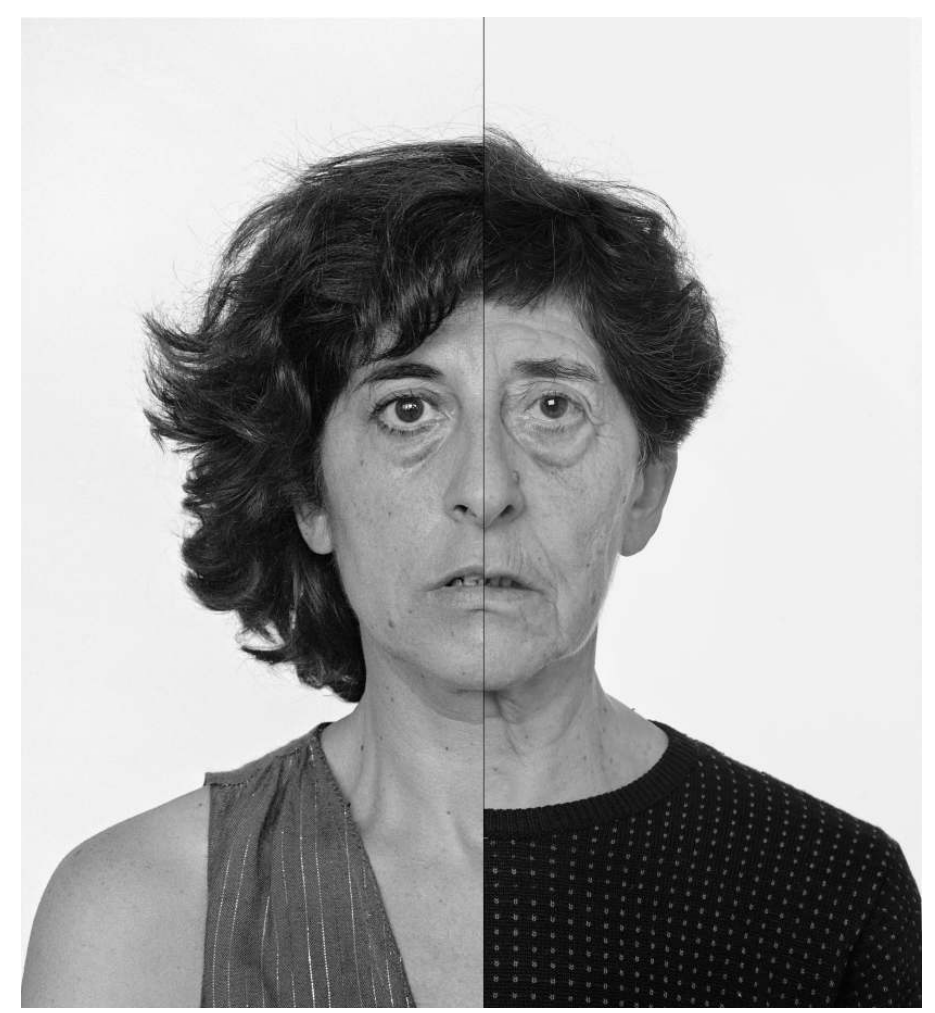

Esther Ferrer, Autorretrato en el tiempo / Self-Portrait in Time, 1981-2014 @ Esther Ferrer, 2014

1 Esther Ferrer is an artist born in the Spanish Basque Country in 1937, who, like a large number of artists from the Iberian Peninsula, moved to France at the beginning of the 1970s.

2 She had already developed an artistic activity in Spain as a member of the group ZAJ, alongside Ramon Barce, Walter Marchetti and Juan Hidalgo, performing an art that can be 
associated with action and concrete musique, and which extensively invoked and showcased the activism of John Cage as a source of inspiration. Her personal work developed once she arrived in Paris by focusing, relatively precociously, on scenic interventions in various spaces or on the streets, and by building up a photochronological repertoire based on the self-portrait in its multiple forms. Such a register is of course aligned with the context of conceptual art and performances, which developed and reached their zenith in those years, though it displayed obvious originality. It is an understatement to say that her performances seem to praise derision or even a form of absurdity and that, as such, they appear a little out of place among the rituals of the moment, more preoccupied with demonstrations a touch more edifying or educative.

This humoristic exaggeration does not, however, stake out any illusory, fictional or even "liberatory" stance, but rather affirms itself in the sphere of the "libertarian", as an opposition to all doctrinal forms of expression. As she points out: "It is difficult not to think of Duchamp or Fluxus when one considers [their] work, but in that case, it is more a question of cousinhood than coupling!"

4 Is it not also obvious that this is very much a "woman" at work? No man indeed seems capable of such machineries or machinations, or if he is, it is via the substitute of a "transvestism", eloquently showing that promiscuity with a toilet plunger or with a cabbage bought at the market is essentially a feminine affair, or rather, in this case, the affair of the Spanish housewife. For Spain is a country heaped in paradoxes, starting with its recognition that a "housewife" works, and that she is therefore not without a profession, as every French identity document discriminatorily states. The feminism that one can identify as driving the work of Esther Ferrer does not in any sense share the militant connotation that criticism in France currently wishes to ascribe to it. Esther Ferrer is a feminist because she is a woman, because in her mind, and in the context in which she has lived and in which she grew up, it goes without saying. She has naturally made her own one of the watchwords of May 68, which saw women claiming that "their body belongs to them", which she exposes by exhibiting nudity and ageing in her photographs, or by using, in an apparently gender-neutral register, "a hammer and nails" in the same way she does "her sewing work", which, among other things, includes suturing her photographed genitalia...

5 Educated in a context where it was duty "to be indignant", Esther Ferrer has never ceased to do so, by conceiving actions in which "the concept transcends the discourse", on the condition that they present "clear-cut situations, open to all interpretations". An art for the ordinary in a way, or rather a "secular" art that leaves the public the possibility of "indulging in bar-room politics" if need be. In addition, for her, the objects she uses in her actions (hammers, clocks, chairs) must lose none of their usefulness, which they can recover after scenic use. It is a contrast that sheds light on the "sacralized" distinction enjoyed by the ready-made and what's more by the relative unpredictability of the objects she chooses for the occasion, leading her to make her selections at the local junk shop. A recognition of the "accidental" that she admits owing to John Cage, and which recommends "being permanently alert to the noises of the world, of which all transcription is only time and duration, and of which one must not fear the unpredictable".

6 That is why Esther Ferrer has the sentiment, if not the certitude, of intervening in a mode of "indefinition", thus distinguishing herself from "some renewal of what are dogmatically known as actions or performances". As such, the artist can be only the 
plinth of an event in which we are supposed to participate, and not the director of a show which, on the face of it, we can only attend. Evidently, this differentiation, however tenuous it might appear, is not only remarkable, but also irrevocable, for it is ethical. Through her work she invites us not only to look, but most of all to act, to contribute. Both by the rhythmics of her installations, the temporal gradations of her self-portraits, and the movements and stases of her actions. She is, undoubtedly, a woman who runs, walks and advances, and who urges us to follow - or precede - her, without omission or interlude.

7 Sources:

8 - Fuera de Formato, Madrid : Centro Cultural de la Villa, 1982

9 - Paris por supuesto, Paris : Casa de España, 1989 (entretien partiellement repris in Tió Bellido, Ramón. L'Art et les expositions en Espagne pendant le franquisme, Paris : Isthme, 2005.)

10 - ZAJ, Madrid: Museo Nacional Centro de Arte Reina Sofia, 1996

11 - Esther Ferrer: de la acción al objeto y viceversa, San Sebastian : Koldo Mitxelena Kulturnea, 1997 ; Séville : Centro Andaluz de Arte Contemporaneo, 1998

12 - Esther Ferrer, Pabellón Español de la Bienal de Venecia, Madrid: Ikusager Ediciones,1999

13 - Esther Ferrer:Al ritmo del tiempo, San Sebastian : Koldo Mitxelena Kulturnea, 2005

14 - Parcerisas, Pilar. Conceptualismo(s) Poéticos/Políticos/Periféricos, En torno al Arte Conceptual en España, 1964-1980, Madrid : Akal, 2007 